IP Periodica Polytechnica Architecture

46(2), pp. 64-69, 2015

DOI: 10.3311/PPar. 8215

Creative Commons Attribution (i)

RESEARCH ARTICLE

\section{Common Visual Language of Architecture and Fine Arts - The Meaning Change of the Square}

\author{
Gábor Üveges ${ }^{1 *}$
}

Received 07 May 2015

\begin{abstract}
The modern and late-modern tendencies of architecture, as well as the geometric abstract trends of fine arts, have, since the beginning of the $20^{\text {th }}$ century, engaged with the same areas of the visual language. Since that time, the creators of the two arts have met, become parallel to and interacted with each other. They have followed the same changes in the intellectual climate, in several cases along the common denominator of a similar approach and geometric language. The same architectonic thinking, very similar structures generated by the same visual basic grammatical operations and the same set of forms can be observed.

At the same time, the meaning - even the meaning of the same formulas of design language - is always changing, depending on the context of the period, intellectual climate, creative approach, world vision, specific field of arts, oeuvre and a number of other conditions.

The meaning of the common 'fetish' of modern fine arts and architecture, that is the meaning of square has continuously changed from period to period and from artist to artist since the beginning of the $20^{\text {th }}$ century; however, since the 70 s onwards and after the post-modern paradigm shift, it changed dramatically, and in a similar way for several artists of both fields of art.

The former meaning of the square turns into almost an opposite concept in the sculpture of Sol LeWitt and the architecture of Arata Isozaki. The visual language invention, functioning similarly for both arts, realized by the American artist and the Japanese architect, is to create a whole beyond rationality, constructed from rational parts by means of overstraining repetition. As a result, this logical system paradoxically leads beyond logic.
\end{abstract}

\section{Keywords}

Architecture and fine arts, architectonic thinking, visual language, change of meaning, square and square grid

\footnotetext{
${ }^{1}$ Department of Design, Faculty of Architecture,

Budapest University of Technology and Economics,

H-1111 Budapest, Mủegyetem rkp. 3., Hungary

${ }^{*}$ Corresponding author, e-mail: rajzi@rajzi.bme.hu
}

In his study 'Introduction to the Theory of the Additional Element in Painting', Malevich points out the overwhelming trend of forms rapidly becoming more geometrical, more angular since the art of Cézanne. (Malevich, 1986:p.9) He explains this self-generating, irresistible artistic process with the presence of an 'additional element intruding into art', comparing it to bacteria. This element, according to Malevich, is the cause for the changes in the structure of artworks, it 'creates a new order while developing the currently valid rule further or by just turning it upside down'. (Malevich, 1986:p.10)

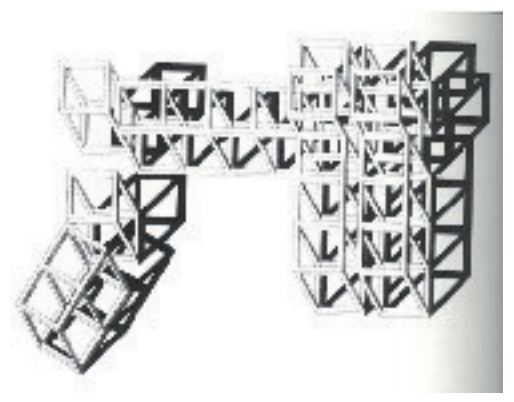

Fig. 1 Arata Isozaki: The basic structure of the Gunma Prefectural Museum of Fine Arts, Takasaki, Japan, 1974 (Source: (Jencks, Ch., 1993))

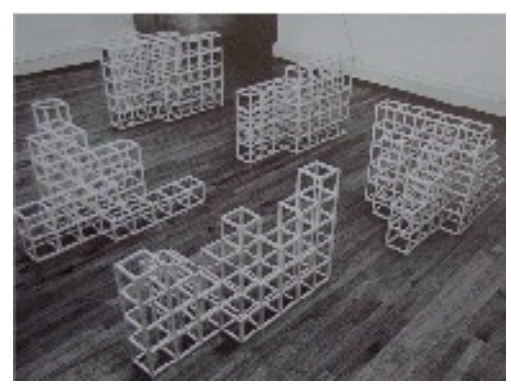

Fig. 2 Sol LeWitt: Five modular structures 1972 (Source: Meyer, J. (2000) Minimalism, Phaidon)

He follows the accelerating process of inverting the rule, starting from Cézanne, through the three phases of Cubism to his cubo-futurist approach that turned into Suprematism. On one hand, Malevich follows an intellectual process that describes searching for the essence, leading from the visible 
to the invisible. On the other hand, he follows the process of the geometric form's principium, which first appears, later becomes dominant and finally exclusive, reaching its end point in Suprematism.

Malevich states: 'the additional element of Suprematism, being embodied as abstract architecture, is the square'. (Malevich, 1986:p.59) He explains the central role of this form not with art philosophical or art historical reasons, but with the internal process of the self-development of form language. As if the square, this Platonic form would have had a real hypnotic effect not only on Malevich but also on the aesthetic sensitivity of the $20^{\text {th }}$-century tendencies aspiring for purity and order 'in the spirit of Apollo', from architecture through the geometric, abstract trend of the fine arts to the design.

Since the beginning of the century, it is as if the square and the cube have lost their magic power; otherwise, the form structure derived from them would be lurking everywhere in these trends. It emerges on the façades and massing of buildings, it 'lurks' in the structure of paintings from Malevich and MoholyNagy through Josef Albers and Max Bill to Francois Morellett and Peter Halley; or in the spatial constructions of the sculptors, from Vantongerlo, Judd, André and Sol Lewitt to Manzoni and Serra. It appears in the form of tiles, household appliances, washing powder boxes, phone boxes and containers, as well as in the plans of apartments and large cities.

Seemingly, largely deprived of its metaphysical contents, square became the 'form of the era' in which the modern Zeitgeist (=spirit of the age) is manifested. As if the structure of this spirit would become visible in the all-encompassing square

1 Since the beginning of the century, the two diametrically opposite approaches, attitudes appearing in different trends of art, can be plastically described in terms of their substantial preferences by the Apollonian and Dionysian dichotomy - previously highlighted by Nietzsche in connection with the Greek art. On one hand, the cool, ascetic, analytical and geometrical tendency of abstraction appears in fine arts; this is the Apollonian side, striving for clear proportions, order, clear structure and transparency, which runs through the $20^{\text {th }}$ century in its successive tendencies (Constructivism, Concrete art, Hard-edge, Minimalism, Neo-geo). On the other hand, conversely, the Dionysian side is continuously present in several tendencies of the fine arts, which is characterized by an instinctive passion, exuberant spontaneity, chaotic nature, randomness, unpredictability and the power of erupting emotions (Expressionism, Cobra, Abstract Expressionism, Informel, New Fauves). The Apollonian, architecturally thinking, geometric abstract fine art tendencies that were shifting towards architecture, accumulated such results during the creative and research work in the border areas between architecture and the visual arts. This meant inspiration and a starting point that could be adapted both from the theory and practice side of the architecture of the $20^{\text {th }}$ century. At the same time, after the paradigm shift of Postmodernism, emphases were refocused within the fine arts. Besides the strengthening of conceptual and post-conceptual tendencies, the geometric abstract aspirations of architectonic thinking were overshadowed. This strict and clear architectural ideal, striving for transparency, clear structures and order, is in the main, far from the recent trends of contemporary art. grid system, and that this grid system would hold the whole 'civilized' modern or now late-modern world together.

In modern architecture, the system of the Cartesian grid meant a coordinate system of universal validity, being independent of place and time; one that could measure and develop the space assumed to be homogenous, continuous and endless on the basis of the modern conception of space, one based on Euclidean geometry. This coordinate system, by means of reason, marked off the orientation points for modern people in the infinite expanse without centre and axis. In the $80 \mathrm{~s}$, in the scene of fine arts, Peter Halley, the prominent figure of the new geometric painting, pointed out that the square, which was considered as some element outside history, as 'ahistoric, a prior conceptual structure, actually very much dependent on context and with no timeless meaning'. (Sturcz, 1999:p.148) Halley - the art of whom was also inspired by the Bauhaus-style architecture of New York - compares the rectangular structures applied by the 'mystics' of geometric abstract painting (Mondrian, Malevich) and the neutral geometry of the Minimalists, and contrasts them with the 'geometry described by Foucault and Baudrillard, which shows how our everyday life is forced inside the limits of geometric systems. The American painter draws attention to the changes in the meaning of the square; and in this regard, he 'contrasts the post-modern square with the modern square'. (Bak, 2003:p.5)

Halley deconstructs the geometric abstract thinking and form language, and examines how the tradition inherited from the great representatives of avant-garde painting can be applied in the changed intellectual climate. The rectangular geometry of the American painter's works is only seemingly abstract, but actually refers to a specific socio-economic environment; and in the form believed to be abstract, we can recognize the 'celllike' spaces, the geometrized material and built world of the big cities in which we live.

On one hand, the square and its derivatives, together with the whole geometric design, connect the artists who are dedicated to the idea of artistic progression. On the other hand, along this common denominator, they convey very different meanings in the concept of Suprematism, Neo-plasticism, Constructivism, Concrete art, Structuralism, Minimalism and Neo-geo within the fine arts, as well as in the context of modern and latemodern architecture.

In Malevich's art, the square is a metaphysical object; for Moholy-Nagy it is the intellectual brick of the constructivist building; in modern architecture, it is mostly the sign of logics, although the red cubic house of Farkas Molnár also refers to some ideological content. Max Bill and Lhose approach the square with a system-based analytical concept; Albers points out the insecurity of the perception of the most elementary things while LeWitt considers the cube as the basic neutral element for the construction of a structure based on a logical system.

'The most interesting characteristic of the cube-says LeWitt - is that it is relatively uninteresting... Therefore, it is the best 


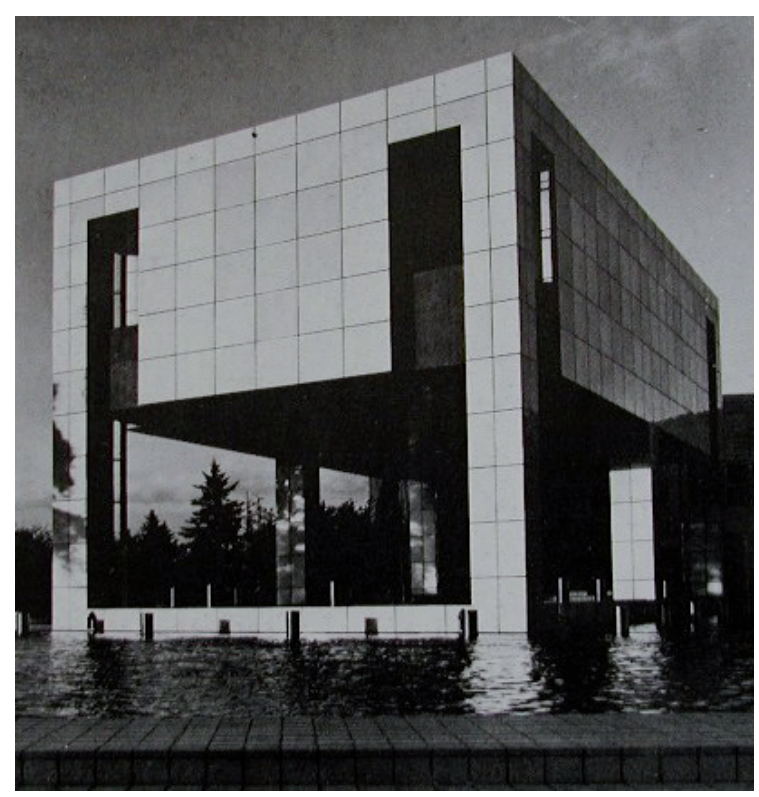

Fig. 3 Arata Isozaki: Gunma Prefectural Museum of Fine Arts, Takasaki, Japan, 1974, (Source: (Jencks, Ch., 1980))

form to use as a basic unit for any more elaborate function, the grammatical device from which the work may proceed.' (Ursprung, 2003:p.9) The cube, the square and the square grid is ... for many architects of Late-Modernism (Isozaki, Ito, Kurokawa, Eisenman) also a basic element used in grammatical operations: they rotate, deform, cut and multiply these forms until losing their original meaning associated with practice and rationality by modern architecture. (Jencks, 1980:p.57) Neither minimalist art nor late-modern architecture wanted a full 'neologism'; both tendencies consciously remained within the existing paradigm of the form language.

'In recent object-type art - as Robert Morris writes - the invention of new forms is not an issue. A morphology of geometric, predominantly rectangular forms has been accepted as a given premise. The engagement of the work became focused on the particularization of these general forms by means of varying scale, material, proportion, placement.' (Morris, 1968:p.243) Similarly to minimalist art, late-modern architecture also accepts the existing form language as a 'given premise'.

'The visual vocabulary of contemporary architecture has all been discovered' - says Arata Isozaki (Jencks, 1980:p.243). On one hand he adapts the form language of modern architecture, on the other hand, he develops it further with a consciously 'mannerist' attitude. In this regard, it shows Isozaki's awareness that he even wrote on the mannerist painting, accurately listing all modern architects from Le Corbusier to Louis Kahn, whose works inspired him.(Jencks, 1980:p.112)

Renewing the abstract form language, accepted as a 'given premise', with an avant-garde radicalism from the direction of minimalist art or the 'mannerist' development of the same form language in late-modern architecture, led to very similar results in Sol LeWitt's art and in Arata Isozaki's architecture,

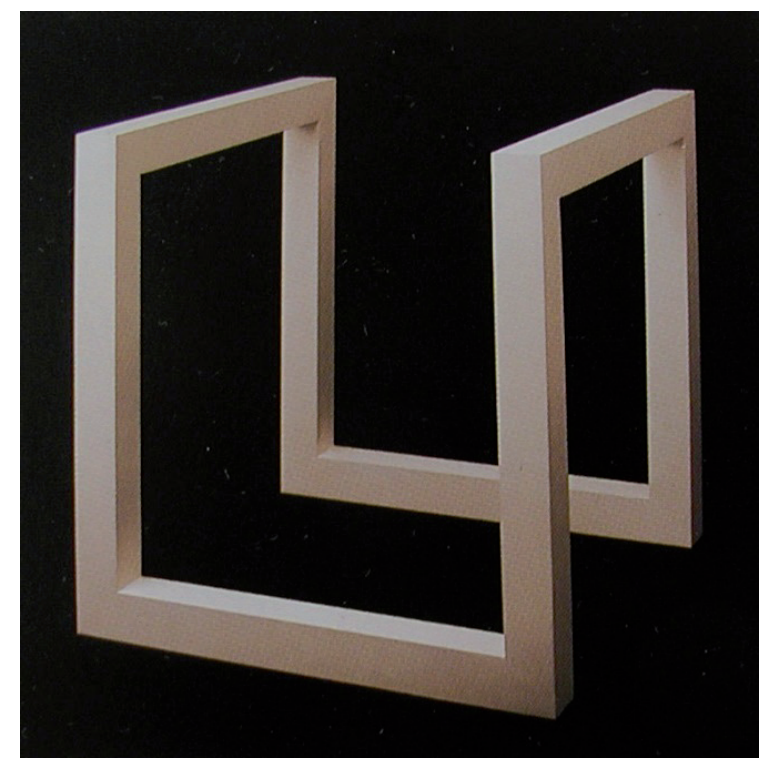

Fig. 4 Sol LeWitt: Incomplete open cube 8/3 1974 (Source: Osborne, P. (2002) Conceptual Art, Phaidon) with regard to the use of square grid structures and to the meaning change of these structures.

The minimalist art of Sol LeWitt is largely architectonic. The artist has repeatedly tried to firmly reject direct architectural associations arising over the interpretation of his works. Nonetheless, he gave titles to some of his works referring to architecture and built some ziggurat-evoking construction, or a structure resembling a three-dimensional X-ray image of an Art-Deco-style skyscraper - although hanging from the ceiling - in the case of which, architectural associations can hardly be avoided. (Friedman, 2000:p.56) LeWitt's receptivity for architectonic thinking was intensified by his experiment, since, in his early period, he worked as a graphic artist in the architect studio of I.M. Pei. Although he did not work as a designer, having barely any attraction to this job either, he even distanced his work from architecture by emphasizing its necessary functionality, (Friedman, 2000:p.56) architecture clearly had an inspiring influence on him. The vertical city in which he lived, the geometry of the settlement, that had already inspired Mondrian, the urban structure of Manhattan organized along a square grid, the contour of the skyscrapers and the transparent mass of the Bauhaus-style office buildings also generated a distant echo in LeWitt's works. When thinking about Conceptual art in his theoretical writings, he addressed such basic issues that also affect architecture by their generality. (LeWitt, 1967:p.213) These are the relationship of the idea, the form and the material, the issues of mass and transparency, simplicity and complexity, scale and size, the syntax of square and cubeorganized systems, and the formal and spatial structures organized in a serial order generated by logic systems. He searched for the possibilities of structure organization by testing every alternative with a systematic consistency. 


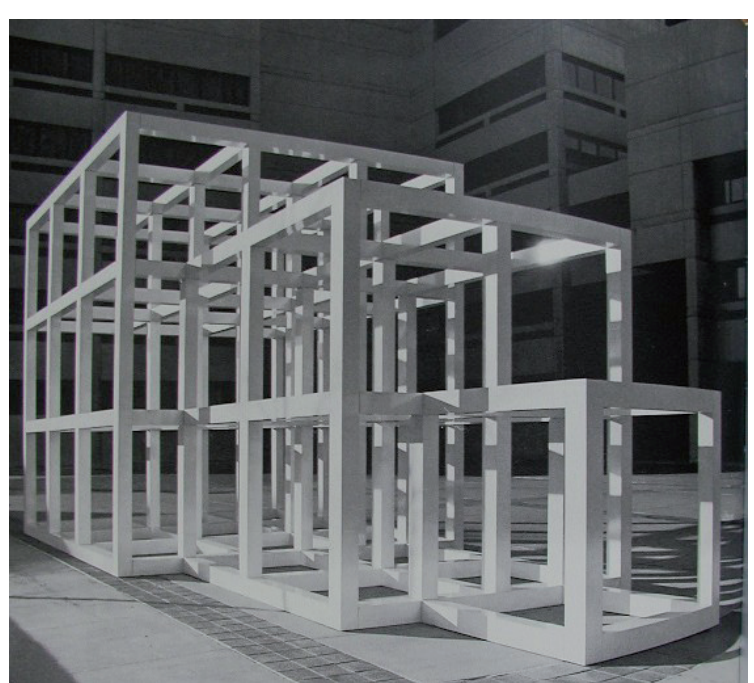

Fig. 5 Sol LeWitt:1 2 3, 1978

(Source: Meyer, J. (2000) Minimalism, Phaidon)

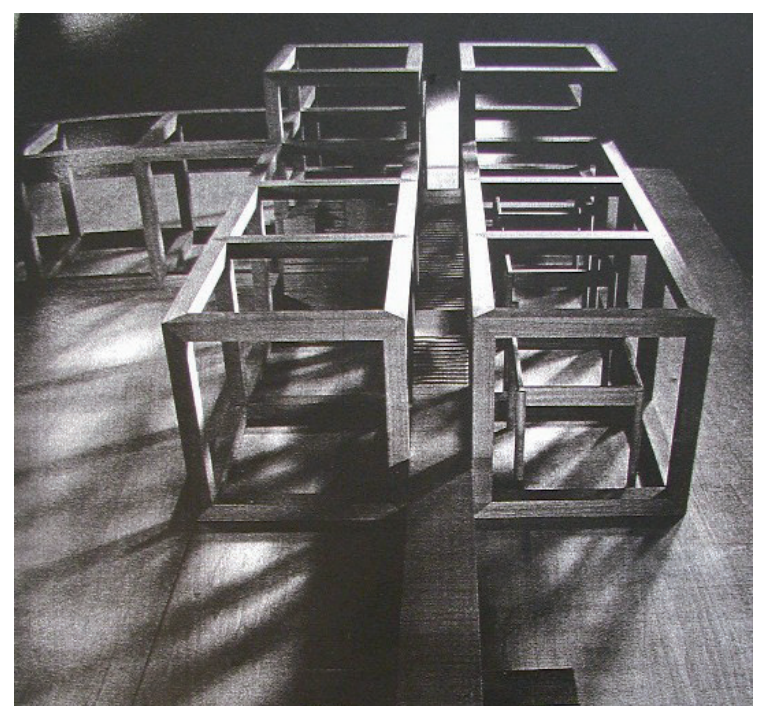

Fig. 6 Arata Isozaki: The model of the basic structure of the Gunma Prefectural Museum (Source: Isozaki, A. (1992) Works 30 Architectural Models, Prints, Drawings)
He recorded all alternatives in charts with an almost scientific precision and revealed, among other things, all imaginable variations of form constellations that can be created by keeping or leaving the edges of a cube in his 'Incomplete open cubes' drawing series. With the omissions, he created a multitude of enigmatic forms from the 'uninteresting' and worn-out cube and recorded them in a logical system. The enigmatic central cube motif of Isozaki's Gunma Museum, formed with similar omissions, seems to fit into LeWitt's system.

The design and construction process, which are usually inseparably overlapped in fine arts, were sharply separated by LeWitt in a way known from architecture. For example, in the case of his monumental wall drawings, he prepared the plan with the gesture of a conceptualist artist, leaving the implementation to his assistant; with this method, he aimed to avoid the manifestation of creative subjectivity in the artwork. According to the principles of Conceptual art, primarily the idea should prevail in the work; moreover, it should dominate over the external appearance. The artist should start with the idea, and in this case - as he himself said - 'The idea becomes a machine that makes the art.' (LeWitt, 1967:p.214) In his late period, he built increasingly complex structures and in addition to the dominance of the idea, more emphasis was laid on the perfectly created artwork. This represents a certain shift in a material direction compared to the dematerializing aspirations of the $60 \mathrm{~s}$.

LeWitt also built his constructions, which were reminiscent of architectural structures, outdoors from brick and concrete, in an architectural scale; and he devoted his last years to planning a synagogue building. (Beth Shalom Synagogue, Chester, Connecticut, 1999) (Friedman, 2000:p.58).

Arata Isozaki's creative period, beginning in the early seventies, was typical of his gesture using an abstract space construction - very similar to the artworks of Sol LeWitt - as the 'basic structure' of his buildings, on which he could place the 'supplemental structure' serving the function. After designing several buildings, this space and structure-creating method reached its highest level of achievement in the building of the Museum of Modern Art, Gunma. Here, Isozaki started from a truss structure organized on a square grid, consisting of 36 pieces of a 12-meter cube module, which he called the 'basic structure,' clad with aluminium panels. This incorporated the museum space, the 'void'; he then built the system of offices, service rooms, stairs and mechanical equipment - called 'supplemental structure' - on top of it. (Isozaki, 1992:p.68)

The museum was born as the complex interaction of these two structures. Moreover, the simultaneous examination of the abstract geometric language and the specific architectural language during the design process also appears in other buildings of this period of Isozaki. The abstract geometric language, the examination of which Isozaki mentioned, is the same language that was examined by LeWitt, and which language they both used very similarly in the organization of the structure.

The 'basic idea of the Gunma Museum - says Isozaki - is the art gallery, as a feeling of emptiness'. (Isozaki, 1992:p.79) In connection with this emphasized emptiness, one might think about the eastern philosophical tradition, but instead of the Zen Buddhist interpretation of emptiness, the Japanese architect gives an understanding associated with agnosticism. Besides the disappearance of God, Isozaki lists the lack of an intellectual centre, the contemporary absence of common faith, knowledge and values, as well as the lack of (classic) scale, harmony and order as the circumstances he defines in the metaphor of the 'degree zero' or 'void at a centre'. This 'void at a centre' lies behind the square grid, the structure and the specific silvergrey colour of the building, as some deeper meaning. (Jencks, 1993:p.106) The 'void at a centre', e.g. the dominance of the 


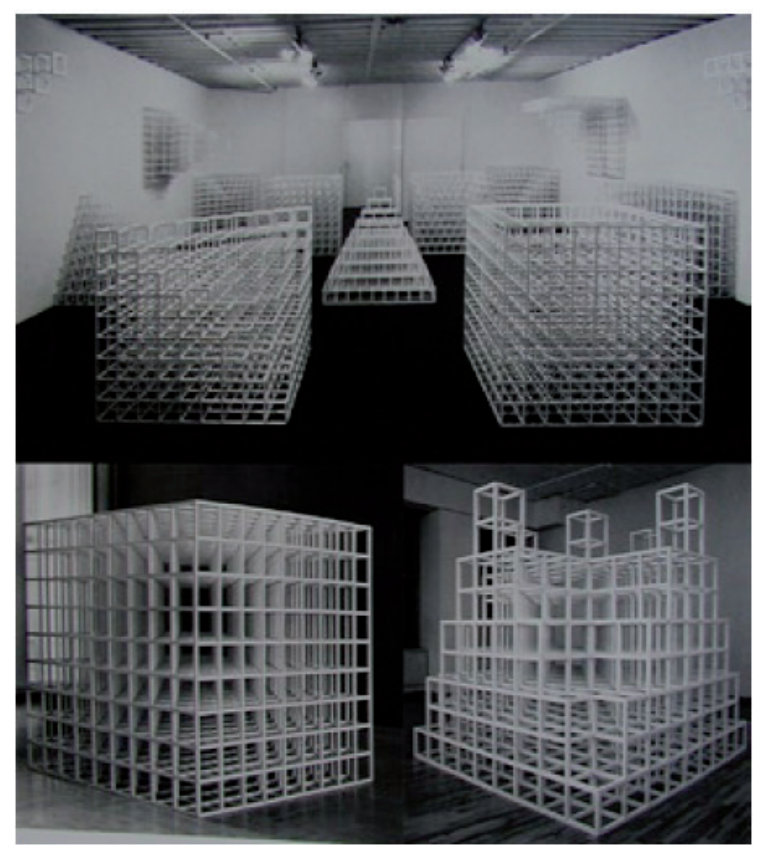

Fig. 7 Installation view of the LeWitt exhibition Structures, New York, 1977, Sol LeWitt: Nine- Part Modular Cube., 1977 Sol LeWitt: Five Towers, 1986 (Source: Meyer, J. (2000) Minimalism, Phaidon)

space is also typical of the structures of LeWitt. But while the minimalist artist, with a radical avant-garde gesture, presents the creative method of the structure based on a logical system as a self-value, and the method itself as an artwork, emphasizing the primacy of the concept and the intellectual principle by means of his 'non-objectiveness' dissolving the mass into space, Isozaki uses his method, which creates complicated structures based on the same extreme repetition - and focuses on emptiness - to convey metaphysical contents.

Of course, the art of LeWitt and the 70s period of Isozaki' architecture are not identical but similar to each other. The feature that still links the two artists, despite some significant differences, both in their attitude and in their design language is, in many ways, the artistic tradition; one that uses a cool, reductivist, geometric abstract form language that carries the intellectual and aesthetic experience of modernity. It is through this common denominator that the American sculptor and the Japanese architect meet each other. In addition, they are also connected by their attitude, one that changes the meaning of cubic structures in a similar way. Their differences point out the possible existence of different approaches, alternatives and methodological systems within the same world of values; while their intellectual position, being identical on the essential issues, can be clearly seen in comparison with the world of values and artistic approach of postmodern classicism or the trans-avant-garde located at the opposite pole of the scale.

While Postmodernism, in many ways, gave up the positions of Modern architecture in the field of theory, also aesthetics and form language, in the case of late-modern architecture including Isozaki's architecture - the architectural programme

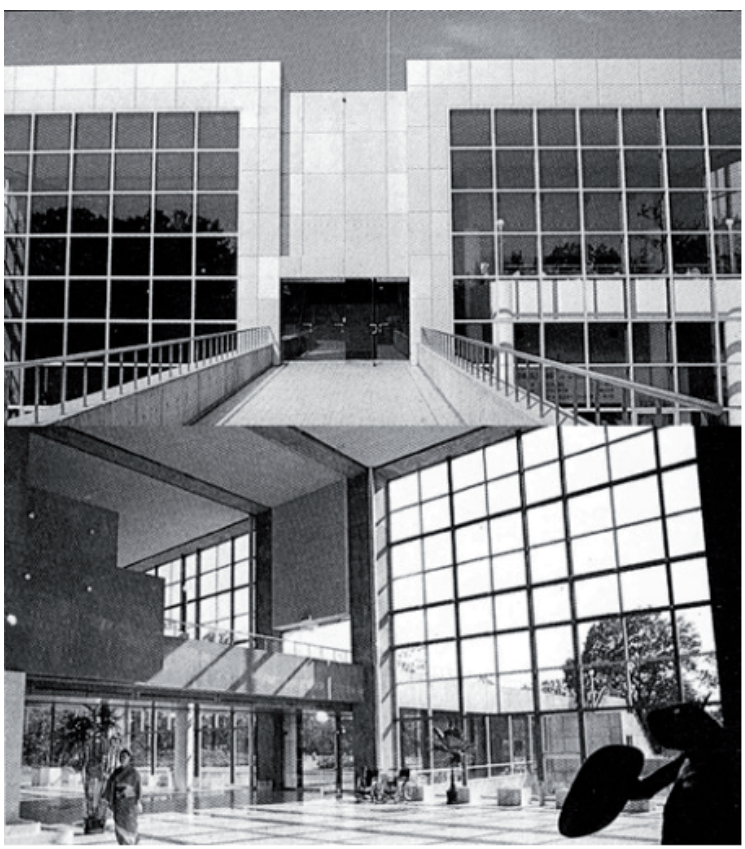

Fig. 8 Arata Isozaki: Gunma Museum, 1974 (Source: (Jencks, Ch., 1980))

meant the reformation of the modern spirit, aesthetics and form language instead of giving them up. Similarly, in the avantgarde aspirations of the sixties and through LeWitt's minimalism, modern art reform itself, which radical renewal means not giving up, continues the avant-garde traditions that are based just on these radical reformations.

LeWitt and Isozaki are the reformers and followers of the modern architectural and artistic trend that can be characterized both by a systematic structure organization, sterile impersonality, a mechanistic and industrial appearance, the construction of serial and modular systems, and universalism in the context of neo avant-garde art, and on the other hand, in the framework of late-modern architecture. In the context of art and architecture, LeWitt and Isozaki use the same geometric abstract form language. They manipulate the same basic element - the square grid structure - and use the same basic operation of repetition to an extreme, creating, from rational components, a whole beyond all rationality. In a similar way, the American artist and the Japanese architect, through the multiplication of the rational grid structure, turns the meaning to the contrary - that is in the direction beyond rationality.

'Conceptual artists are mystics rather than rationalists. They leap to conclusions that logic cannot reach.' - as Sol LeWitt makes clear from the very beginning of his writing, 'Sentences on Conceptual Art'. (LeWitt, 1967:p.323) By the adaption of a logical system in space, LeWitt generates a seemingly rational, exact form structure that seems to dissolve in space - according to his monographer, Martin Friedman - 'In effect, this constellation of incomplete cubes is a philosophical disquisition on present reality dissolving into nothingness.' (Friedman, 2000:p.56) 
Isozaki also dissolves the building mass and makes it elusive and dematerialized. The silver grey glitter of the aluminium panels covering the façade of Gumma Museum make the building perceivable as a grey elusive dimension; according to Isozaki's intention, it conveys such metaphysical qualities which he summarizes in the metaphor of 'shadowless twilight'. This results in the disappearance of reality, with light and shadow in the twilight gloom, as well as in the appearance of illusion through the minimization of differentiation that is the visual difference. (Jencks 1993:p.105) Both Isozaki and LeWitt arrive at the paradoxical phenomenon when clear structure becomes obscure and difficult to catch, and reality becomes blurred. In the case of the Japanese architect, this occurs in the lighting conditions of shadowless twilight, while, for the works of the American artist, it happens when the logical system leads beyond logic, and structure, under certain light, takes on an elusive spiritual dimension'. (Friedman, 2000:p.56)

'The accumulation of facts collapses perception. The indicated sum of these simple series is irreducible complexity. Moreover, impenetrable chaos.' - writes Mel Bochner on the works of LeWitt. (Bochner, 1966:p.226) The same contradiction is emphasized by Jencks as a characteristic of the late-modern architectural language: 'grids are used to confuse and disorient where previously, they were used to order'. (Jencks, 1980:p.57)

The 'fetish' of modern architecture and art, namely the square, has not only a presence in the art of Sol LeWitt and the architecture of Arata Isozaki, but it is present everywhere by its countless repetition horizontally and vertically, to left and right, this way blurring the main directions. Both creators intensify the presence of the square, cube and square grid to omnipresence. With this method, they achieve the dissolution of the regular system both in the case of sculptures and buildings; the clear structure becomes blurred and dematerialized, the rational grid structure turns into irrationality and the paradox of 'irrational rationalism' that was emphasized by Jencks as a characteristic of late-modern architecture, also appearing earlier in minimalist art, is created. (Jencks, 1980:p.57)

\section{References}

Bak, I. (2003) Posztmodern négyzetek, avagy a metafizika alakulása. (Postmodern squares or the metamorphosis of the metaphysics.) In: Bak, I. 2001-2005, Katalógus

Bochner, M. (1966) Sol LeWitt . In: Meyer, J. Minimalism. Phaidon

Friedman, M., (2000) Construction Sights. In: Sol LeWitt-A Retrospective, Yale University Press

Isozaki, A. (1992) Works 30 Architectural Models, Prints, Drawings

Jencks, Ch. (1980) The Rhetoric of Late-Modernism. In: Jencks, Ch. LateModern Architecture, Academy Editions, London

Jencks, Ch. (1980) The pluralism of Japanese Architecture. In: Jencks, Ch. Late-Modern Architecture. Academy Editions, London

Jencks, Ch. (1993) Architecture Today. Academy Editions, London

LeWitt, S. (1967) Paragraphs on Conceptual Art. In: Meyer, J Minimalism. Phaidon

LeWitt, S. (1967) Mondatok a „Konceptuális Művészetről”. (Paragraphs on Conceptual Art.) In: Aknai, T. Egyetemes müvészettörténet 1945-1980. (Universal Art History 1945-1980.) Dialóg Campus Kiadó, BudapestPécs

Malevics, K. (1986) A festészet lappangó elemének elmélete. (Introduction to the theory of the additional element in painting.) In: Malevics, K. A tárgynélküli világ. (The non - objective world.) Corvina

Morris, R. (1968) Anti-Form. In: Meyer, J. Minimalism. Phaidon

Sturcz, J. (1999) Neogeo, Peter Halley, Ross Bleckner, Philip Taaffe. In: Sturcz, J. Janus félúton. Új Müvészet Kiadó

Ursprung, P. (2003) Minimalism and Minimal Art. In: Ruby, I., Ruby, A., Sachs, A., Ursprung, P. Minimal Architecture. Prestel, Munich-London 